\title{
Основные тенденции развития оптоэлектронной техники до 2030 года
}

\author{
А.С. Башкатов, Д.Н. Мещерова \\ Мытищинский научно-исследовательский институт радиоизмерительных приборов, \\ Мытиши, Московская область
}

DOI 10.34077/RCSP2019-25

В результате выполнения ОКР по программе развития ЭКБ в период 2011 - 2018 годов достигнуты определенные успехи в создании современных изделий квантовой электроники и компонентов ВОСП:

- разработан ряд матричных и линейных фоточувствительных приборов с переносом заряда на основе кремния для видимой и ближней ИК области спектра (0,4-1,0 мкм); матричные кремниевые КМОП-фотоприемники формата $1024 \times 1024$ с повышенной радиационной стойкостью; фотоприемные модули для спектральных диапазонов 3-5 и 8-10 мкм на основе гетероэпитаксиальных структур кадмий-ртуть-теллура и антимонида индия; фотоприемные модули для ИК области 0,9-1,7 мкм; фотоприемные устройства для ультрафиолетового (УФ) поддиапазона (260-280 мкм и 290-340 мкм; ряд быстродействующих лавинных ФПУ;

- разработана решетка лазерных диодов со средней мощностью импульса лазерного излучения $1500 \mathrm{BT}$;

- разработан унифицированный ряд гетеролазеров повышенной радиационной стойкости с длинами волн излучения 780 нм, 794,7 нм и 852,1 нм. Завершается разработка отечественного радиационно-стойкого волокна и оптического кабеля на его основе.

В качестве важных направлений развития и задач для фоточувствительных приборов, изделий квантовой электроники и компонентов ВОСП в прогнозируемый период следует выделить следующие:

- имеется потребность и дефицит в части создания ряда отечественных лавинныхи pin-фотодиодов и приемных модулей на их основе с высоким быстродействием (граничная частота $10-50$ ГГц) с различными размерами фоточувствительных элементов для области1300 - 1600 нм, как для информационных систем так и для радиофотонных схем;

- к 2020 году будет разработан ріn-фотодиод с граничной частотой 2,5 ГГц. Требуется разработка отечественной промышленной технологии и серийный выпуск квантово-каскадных излучателей с высоким значением пиковой мощности излучения в диапазоне длин волн 3-5 мкм и 8-12 мкм;

- необходима разработка оптоэлектронных модулей для передачи и приема аналоговых сигналов с полосой частот модуляции до 30 ГГц для использования в специальных системах передачи и обработки информации, волоконно-оптических системах передачи информации по каналам РЛС, ФАР и АФАР;

- для систем навигации, обнаружения необходима разработка оптоэлектронных модулей для передачи и приема цифровых сигналов со скоростью передачи информации до 10 ГГбит/с. Требуется разработка промышленной технологии изготовления отечественных ОВ на длины волн 1,3 и 1,55 мкм и создание на их основе оптических кабелей для аппаратуры различного назначения;

- в интересах комплексов наблюдения за воздушным пространством и систем передачи информации требуется разработка многоканальных волоконно-оптических преобразователей, в том числе комбинированных и погружных;

- необходима разработка волоконно-оптических аттенюаторов фиксированных и с переменным управлением. Фотонных интегральных схем, как сочетание кремниевой технологии и технологии интегральной оптики.

Данные направления будут использоваться для волоконно-оптических систем передачи и распределения аналоговых СВЧ-сигналов и цифровых сигналов управления ФАР, АФАР РЛС различного назначения, а также многопозиционных РЛС для межмодульного обмена опорными частотами и синхросигналами требуется разработка таких компонентов ВОСП нового поколения как ВОЛЗА и ФВО аналоговых СВЧ-сигналов. 